\title{
ANALISIS PERTIMBANGAN KOMISI PENGAWAS PERSAINGAN USAHA TERHADAP PELANGGARAN OLEH PERUSAHAAN PENERBANGAN BADAN USAHA MILIK NEGARA (STUDI PUTUSAN No. 15/KPPU-I/2019)
}

\section{THE CONSIDERATION ANALYSIS OF COMMISSION FOR THE SUPERVISION OF BUSINESS COMPETITION VIOLATIONS BY STATE-OWNED BUSINESS AGENCY FLIGHT COMPANIES (DECISION STUDY No. 15/KPPU-I/ 2019)}

\author{
Faisal Fachri \\ Universitas Pembangunan Nasional Veteran Jakarta \\ faisalfachri@upnvj.ac.id \\ Iwan Erar Joesoef \\ Universitas Pembangunan Nasional Veteran Jakarta
}

\begin{abstract}
Abstrak
Penelitian ini bertujuan untuk memahami konsep monopoli yang dilakukan BUMN pada sektor penerbangan dan upaya menanggulanginya. Metode yang di gunakan didalam penelitian ini ialah metode pendekatan yuridis normatif menggunakan data sekunder yaitu data yang di peroleh dari tinjauan kepustakaan. Tipe penelitian yang di lakukan dalam penulisan ini adalah penelitian hukum (legal reseacht) yaitu penelitin yang mengkaji rumusan masalah yang terdapat dalam penelitian dengan meneliti peraturan perundang-undangan terkait yang berlaku. Kesimpulan penelitian bahwa Badan Usaha Milik Negara adalah perusahaan negara yang diberikan pengecualian untuk memonopoli pangsa pasar demi kepentingan dan kesejahteraan orang banyak. Metode pendekatan per se illegal digunakan untuk mengetahui dampak yang ditimbulkan atas perbuatan yang diduga melanggar persaingan usaha. Good corporate govermence dapat dijadikan sebagi acuan dalam menentukan setiap tindakan yang dilakukan oleh perusahaan Badan Usaha Milik Negara didalam pangsa pasar bersifat mendorong atau menghambat persaingan.
\end{abstract}

Kata Kunci: Badan Usaha Milik Negara, Pelanggaran Persaingan Usaha, Praktik Monopoli

\begin{abstract}
The purpose of this research to understand the monopoly concept carried out by state-owned enterprises in the aviation sector and efforts to overcome it. The method used in this study is a normative juridical approach using secondary data, namely data obtained from literature reviews. The type of research carried out in this paper is legal research, namely research that examines the formulation of problems contained in research by examining the relevant laws and regulations that apply. The conclusion of this research is that State-Owned
\end{abstract}


Enterprises are state-owned companies that are granted exemptions to monopolize market share for the benefit and welfare of the people. The per se illegal approach method is used to determine the impact of an alleged violation of business competition. Good corporate governance can be used as a reference in determining any actions taken by State-Owned Enterprises in market share to encourage or inhibit competition.

Keywords : State Owned Enterprises, Violation of Business Competition, Monopolistic Practices

\section{A. Pendahuluan}

Perkembangan di dunia usaha pada saat ini membuat persaingan usaha sangat bervariasi tidak menutup kemungkinan pula pelaku usaha menggunakan cara-cara yang tidak di benarkan dalam proses persaingan dalam dunia usaha yang menyebabkan pelanggaran bagi persaingan usaha. Persaingan itu sendiri merupakan sebuah kegiatan diantara pesaing didalam pasar untuk memperoleh apa yang diinginkan didalam pangsa pasar berupa daya beli yang tinggi oleh masyarakat atas produk yang ditawarkan masing-masing pelaku usaha. ${ }^{1}$ Termaktup dalam Pasal 33 Undang-Undang Dasar 1945 mengenai acuan kebijakan politik perokonomian bangsa serta hukum perekonomian bangsa Indonesia harus menjunjung dasar falsafah demokrasi ekonomi kerakyatan. ${ }^{2}$

1 Mudrajat Kuncoro, Strategi Bagaimana Meraih Keunggulan Kompetitif, (Jakarta: Erlangga, 2005), hlm. 86.

2 Rachmadi Usman, Hukum Persaingan Usaha Di Indonesia, (Jakarta: Gramedia Pustaka Utama, 2004), hlm. 10.
Terealisasinya proses persaingan yang wajar diantara pelaku usaha dalam pangsa pasar menggambarkan hukum telah berjalan dengan semestinya, namu pada praktiknya masih banyak pelaku usaha yang masih belum bisa menerapkan perintah persaingan usaha yang sehat sehingga menjadikan pelanggaran terhadap prinsip persaingan itu sendiri. Agar dapat terciptanya pangsa pasar yang sehat dengan rasa keadilan yang merata bagi setiap pelaku usaha, maka setiap kegiatan usaha yang dilaksanakan oleh siapapun harus terhindar dari kegiatan yang dapat mencederai persangan usaha yang sehat. ${ }^{3}$

BUMN merupakan bentuk implementasi penjamin kesejahteraan masyarakat. BUMN diartikan sebagai badan usaha yang melaksanakan perintah negara karena sebagian besar atau seluruh

\footnotetext{
${ }^{3}$ Binoto Nadapdap, Hukum Acara Persaingan Usaha, (Jakarta: Jala Permata Aksara, 2009), hlm. 3.
} 
modal usahanya dimiliki negara. ${ }^{4}$ Dalam pelaksanaanya BUMN di kecualikan untuk memonopoli pangsa pasar atas kepentingan negara dalam menjamin kesejahteraan umum yang termaktup dalam Pasal 33 ayat (2) Undang-Undang Dasar 1945 pada dasarnya dapat dikecualikan pada sektor tertentu yang berhubungan dengan kesejahteraan orang banyak. $^{5} \quad$ Pelaksana monopoli yang di kecualikan terdapat pada Pasal 51 UndangUndang Nomor 5 Tahun 1999 yang mana harus diselenggarakan oleh BUMN atau instansi yang di tunjuk oleh pemerintah ${ }^{6}$. Monopoli memang pada prinsipnya dapat di kecualikan namun untuk pelaksanaan praktik monopoli tidak dapat di kecualikan dan di benarkan. Posisi BUMN sebagi pelaku usaha lebih di untungkan dalam pangsa pasar, namun hal tersebut kerap kali disalah gunakan yang mengakibatkan penyelewengan terhadap Undang-Undang Nomor 5 Tahun 1999 oleh perusahaan BUMN sendiri.

\footnotetext{
4 Undang-Undang Nomor 19 Tahun 2003 Tentang Badan Usaha Milik Negara, Pasal 1 Ayat (1).

${ }^{5}$ Pasal 33 Undang-Undang Dasar 1945

6 Undang-Undang Nomor 5 Tahun 1999 Tentang Larangan Praktek Monopoli dan Persaingan Usaha Tidak Sehat
}

Berbagai kegiatan dan perjanjian yang dilarang dikenal didalam prinsip pelaksanaan persaingan usaha yang sehat agar menciptakan keadilan bagi setiap pelaku usaha, termasuk aktivitas perjanjian yang dilarang dimana diantara pelaku usaha ketika melaksanakan kegiatannya dengan maksud membatasi pesaing lain dan dapat merugikan pelaku usaha lain. Adanya anggapan pelaku usaha yang memiliki ekonomi lebih sejahtera akan mempengaruhi pelaku usaha dibawahnya yang dirasa tidak memberi keadilan. ${ }^{7}$ Jika kita amati pada setiap transaksi bisnis yang dilakukan para pelaku uaha tidak terlepas dari perjanjian antar pelaku usaha untuk saling menunjang kegiatan usahanya. Dalam penelitian ini membahas mengenai pelanggaran perjanjian penetapan harga merupakan sebagian bentuk perjanjian yang tidak diperbolehkan dalam persaingan usaha, yakini dengan maksud memperoleh laba setinggi mungkin dari setiap kegiatan yang dilakukan pelaku usaha yang terlibat. Dampak dari perjanjan penetapan harga ini mengarah kepada kemampuan dalam mengatur harga dalam pangsa pasar, dengan demikian akan diperolehnya kekuatan untuk menguasa

\footnotetext{
${ }^{7}$ Gunawan Widjaja, Seri Hukum Bisnis Marger Dalam Perspektif Monopoli, (Jakarta: Raja Grafindo Persada, 2002), hlm. 23.
} 
pasar dengan mengontrol harga yang dapat mengganggu pesaingnya dengan menimbulkan dampak yang merugikan bagi pelaku usaha lain. ${ }^{8}$

Dalam persaingan usaha mengenal dua prinsip pendekatan masalah yaitu prinsip rules of reasons dan per se ilegall, yang dimaksud dengan prinsip rules of reasons adalah suatu metode pendekatan masalah untuk membuat evaluasi mengenai akibat yang di timbulkan dari setiap kegiatan terhadap prinsip persaingan yang sehat, ${ }^{9}$ prinsip per se illegal diartikan sebagi sebuah metode pendekatan masalah yang ditafsirkan jika setiap tindakan atau perbuatan perjanjian yang dilakukan tidak sesuai dengan prinsip persaingan yang sehat, maka tanpa melakukan proses pengungkapan fakta lebih lanjut mengenai dampak yang dapat mempengaruhi persaingan usaha tidak sehat atas tindakan perjanjian yang dilakukan. ${ }^{10}$ Penyalah gunaan posisi dominan yang di miliki BUMN sebagai perusahaan negara yang di berikan hak untuk memonopoli berbagai sektor ekonomi demi kepentingan orang

\footnotetext{
${ }^{8}$ Andi Fahmi Lubis dkk, "Hukum Persaingan Usaha Antara Teks Dan Konteks" (Jakarta: KPPU, 2009), hlm. 91.

${ }^{9}$ Ibid, hlm. 55.

${ }^{10}$ lbid, hlm. 56.
}

banyak tak kala dalam pelaksanaanya tidak selalu sesuai dengan batasan yang diperbolehkan sesuai Perundangundangan. Dalam memikul tanggung jawab atas wewenangnya KPPU diharuskan untuk menciptakan persaingan yang sehat, didalam praktiknya KPPU masih menemukan kasus pelanggaran terhadap persaingan usaha yang di lakukan oleh BUMN seperti kasus yang akan di angkat oleh penulis mengenai kasus pelanggaran persaingan usaha oleh maskapai penerbangan dibawah naungan BUMN hal ini lah yang menjadi perhatian penting bagi KPPU selaku instansi negara sebagai pelaksana untuk mengawasi serta menciptakan iklim persaingan yang sehat.

Bahwa dugaan pelanggaran yang terjadi di sektor penerbangan tersebut dengan adanya harga tiket pesawat angkutan niaga berjadwal kelas ekonomi berjadwal jangkauan dalam negri pada awal tahun 2019 dirasakan masyarakat masih cukup tinggi meski masa peak season sudah berakhir. Masyarakat menilai harga tiket pesawat tinggi saat peak season masih wajar, karena secara umum terjadi peningkatan permintaan masyarakat namun setelah peak season harga tidak kunjung normal. Adanya kecenderungan terkonsentrasi struktur pasar di industri angkutan udara pada penerbangan dalam 
negri oleh beberapa maskapai penerbangan, terlebih lagi konsentrasi pasar tersebut semakin tinggi ketika Garuda Group melakukan Kerja Sama Operasi (KSO) dan/atau Kerja Sama Manajemen dengan Sriwijaya Group pada periode November 2018 yang selanjutnya juga memicu adanya pelanggaran terhadap persaingan.

Dari latar belakang pembahasan penelitian yang penulis kaji bahwasanya dapat ditarik permasalahan inti yang akan dikaji berupa pelanggaran persaingan usaha tidak sehat dilakukan oleh perusahaan penerbangan BUMN dan bagaimana pertimbangan KPPU dalam memutus perkara Putusan nomor 15/KPPU-I/2019 atas perusahaan BUMN. Dengan demikian dari penelian ini untuk mengetahui bagaimana pelanggaran persaingan usaha tidak sehat dilakukan oleh perusahaan penerbangan BUMN serata untuk memahami bagaimana pertimbangan KPPU dalam memutus perkara Putusan nomor 15/KPPU-I/2019 atas perusahaan BUMN

\section{B. Metode Penelitian}

Tipe penelitian berupa penelitian hukum (legal reseacht). Metode pendekatan yang digunakan adalah peraturan perundang-undangan (statute approach), pendekatan kasus (case approach) serta pendekatan konseptual (conceptual approach).

Cara memperoleh data penlisan ini melalui studi kepustakaan dengan mencari kasus terkait,setelah mendapatkan bahan terkait lalu di lakukan studi kepustakaan dengan mempelajari dan menganalisis sumber data yang berkaitan dengan rumusan masalah.

\section{Pembahasan}

\section{Pelanggaran persaingan usaha tidak sehat dilakukan oleh Perusahaan penerbangan BUMN}

Pada dasarnya negara memiliki hak untuk memonopoli. Negara melalui BUMN dalam pangsa pasar dapat dikecualikan untuk memonopoli pasar sesuai dengan Pasal 33 ayat (2) UndangUndang Dasar 1945. Berdasarkan Pasal 1 ayat (1) Undang-Undang Nomor 5 Tahun 1999, monopoli diartikan sebagai penguasaan dalam pangsa pasar yang dilakukan oleh satu atau sekelompok pelaku usaha mengenai pembuatan dan atau penjualan barang dan/atau atas penggunaan jasa tertentu ${ }^{11}$. Dari definisi praktik monopoli diatas dapat

\footnotetext{
11 Undang-Undang Nomor 5 Tahun 1999 Tentang Larangan Praktik Monopoli Dan Persaingan Usaha Tidak Sehat.
} 
disumpulkan empat hal yang mendasar, sebagai berikut :

1. Terpusatnya kekuatan ekonomi didalam pangsa pasar

2. Penguasaan pasar terpusat pada satu atau lebih pelaku usaha

3. Akibat dari penguasaan pasar mencederai perinsip persaingan usaha yang sehat

4. Penguasaan pasar tersebut mengakibatkan kerugian bagi kepentingan umum.

Perbuatan praktik monopoli ini berupa upaya mempertahankan atau meningkatkan posisi monopoli. Kekuatan dalam mengontrol pasar merupakan sebuah kemampuan yang dimiliki pelaku usaha akibat dari hak monopoli yang dimilikinya, penyalahgunaan dari kekuatan monopoli yang diperoleh suatu pelaku usaha dapat bertindak kepada kegiatan yang dapat membatasi atau menghilangkan tekanan terhadap persaingan salah satunya dengan menentukan harga, sehingga dapat membatasi (entry barriers) pelaku usaha baru dalam pasar

Transportasi udara merupakan sebuah layanan transportasi yang sangat dibutuhkan pada saat ini, dengan memiliki beberapa keunggulan dari transportasi udara salah satunya memiliki jangkauan yang lebih luas dan mampu menjangkau dari suatu daerah ke daerah lain dengan jarak tempuh yang relatif cepat dan sulit dijangkau dengan moda transportasi darat atau pun transportasi laut karena keadaan geografis. ${ }^{12}$ Pengaturan pelaksanaan sektor transportasi udara harus berada dibawah kendali negara langsung demi menjamin kesejahteraan orang banyak. Pada prinsipnya penerbangan harus berlandaskan pada penyelenggaraan kegiatan penerbangan yang terstruktur agar mampu menjamin keselamatan dan kenyamana pengguna jasa termasuk terhadap harga yang merakyat, dan selalu memperhatikan prinsip persaingan usaha yang sehat. ${ }^{13}$

Faktor yang dapat mempengaruhi pelanggaran persaingan usaha dikenal dengan perjanjian yang tidak diperbolehkan dan kegiatan yang tidak diperbolehkan, yaitu kegiatan diantara pelaku usaha dalam melaksanakan kegiatannya dengan maksud membatasi pesaing lain dan dapat merugikan bagi pelaku saha lain atau pesaing didalam

\footnotetext{
12 Hutagaol, "Penerbangan Perintis Dalam Mengembangkan Perekonomian Di Pulau Karimun Jawa," Jurnal Manajemen Transportasi \& Logistik Vol. 05 N (2018): 162.

13 "Pasal 1 Undang-Undang Nomor 1 Tahun 2009 Tentang Penerbangan
} 
pangsa pasar. ${ }^{14}$ Kegiatan yang dilarang didefinisakan sebagai suatu kegiatan melakukan penguasaan pasar atas suatu produk dan pemasaran mengenai barang dan atau jasa tertentu yang dilakukan oleh pelaku usaha terkait dengan mengakibatkan kerugian bagi pelaku saha lain atau pesaing didalam pangsa pasar. ${ }^{15}$ Muatan dari Pasal 51 Undang-Undang Nomor 5 Tahun 1999 mengatur materi memuatan prihal hubungan yang kompleks antara hukum persaingan usaha dengan Badan Usaha Milik Negara sebagai penjamin kesejahteraan orang banyak, yang secara internasional masih dipertentangkan. Berpedoman pada negara-negara maju dengan sistem ekonomi yang lebih modern yang telah menghentikan hak untuk monopoli negara yang baru, yang mana pengontrolan terhadap monopoli negara dilakukan melalui hukum persaingan usaha agar memberi keadilan dan daya saing yang

14 Undang-Undang Nomor 5 Tahun 1999 Tentang Larangan Praktik Monopoli Dan Persaingan Usaha Tidak Sehat Pasal 4 Ayat (1)

15 Undang-Undang Nomor 5 Tahun 1999 Tentang Larangan Praktik Monopoli Dan Persaingan Usaha Tidak Sehat Pasal 17 Ayat (1) sehat didalam pasar. ${ }^{16}$

Pada tahun 2019 terdapat lima kasus adanya indikasi pelanggaran persaingan usaha yang dilakukan perusahaan penerbangan yang diusut dan ditangani Komisi Pengawas Persaingan Usaha, berupa pelanggaran adanya dugaan dihalang-halanginya penjualan tiket maskapai Air Asia pada agent travel online, terdapat dugaan kasus rangkap jabatan yang dilakukan antara PT. Garuda Indonesi dengan PT. Sriwijaya Air, adanya dugaan pelanggaran penetapan tarif kargo, dugaan pelanggaran penetapan harga dan kartel tiket pesawat domestik, serta travel umrah yang dengan salah satu maskapai yang terlibat yakini PT Garuda Indonesia. $^{17}$

Pelanggaran persaingan usaha rangkap jabatan dapat diartikan jika seseorang menduduki jabatan yang penting dalam dua perusahaan yang bergerak dalam pasar sejenis atau dua perusahaan yang bersaing (direct interlock) dengan demikian akan berpotensi besar menimbulkan hubungan horizontal yang mana dapat pula

\footnotetext{
${ }^{16}$ Knud Hansen, "Undang-Undang Larangan Praktek Monopoli Dan Persaingan Usaha Tidak Sehat" (Jakarta: PT Tema Baru, 2002).

${ }^{17}$ KPPU, "Siaran Pers - KOMISI PENGAWAS PERSAINGAN USAHA," https://kppu.go.id/siaran-pers/, diakses 28 Desember 2020 pukul 15.20 WIB
} 
menimbulkan strategi bersama seperti penetapan harga, penetapan jumlah produksi, dan alokasi pasar. ${ }^{18}$ Dan dapat pula menjadikan adanya indikasi hubungan vertikal yang mengakibatkan integrasi vertikal dalam pangsa pasar bersangkutan. Dengan memiliki kekuatan penguasaan pasar oleh pelaku usaha hal ini dapat menjadikan cikal bakal terjadinya tindakan prilaku anti persaingan yang menyebabkan pelanggaran persaingan usaha, yang mana dapat menimbulkan dampak merugikan berbagai kalangan mulai dari pemerintah, pelaku usaha pesaing, serta masyarakat sebagai konsumen. Dengan demikina para pelaku usaha tersebut mampu mengontrol pangsa pasar dengan menetapkan berbagai syarat perdagangan yang menyulitkan pelaku usaha lain dengan maksud membatasi persaingan diantara para pelaku usaha sejenis didalam pangsa pasar, dengan demikian konsumen dirugikan karena tidak mendapatkan persaingan mengenai harga maupun kualitas atas barang atau jasa yang ditawarkan dalam pangsa pasar. Kegiatan usaha demikian dengan membatasi persaingan diantara pelaku usaha sejenis atau membatasi pelaku usaha

18 Undang-Undang Nomor 5 Tahun 1999 Tentang Larangan Praktik Monopoli Dan Persaingan Usaha Tidak Sehat Pasal 26 lain untuk bersaing didalam pangsa pasar dapat berpotensi kepada tindakan kriminal. $^{19}$

Kegiatan kartel merupakan sebuah perilaku dengan adanya persekongkolan atau persekutuan yang dilakukan oleh beberapa pelaku usaha sejenis, dampak dari kegiatan persekongkoan ini terjadi diantara pelaku usaha yang terlibat agar mampu mengontrol produksi, harga, atau penjualannya untuk memperoleh posisi monopoli ${ }^{20}$ Mengutip pendapat dari Didik J. Rachbini apabila didalam pangsa pasar sejenis para pelaku usaha melakukan kordinasi dengan tujuan mengontrol pasar, dapat dikatakan kegiatan tersebut merupakan sebagai praktik kartel, dengan maksud untuk dapat menetapkan harga, jumlah produksi barang, dan pembagian wilayah pemasaran. Kegiatan tersebut dapat dikatagorikan sebagai pengendalian pasar secara horizontal (horizontal restraint).$^{21}$ Pelanggaran kartel ini sendiri pada peraktiknya sangat sulit untuk

19 Anang Triyono, Penyalahgunaan Posisi Dominan Oleh Pelaku Usaha: Studi Kasus Pada Audit PT Telekomunikasi Indonesia Tbk" (Universitas Indonesia, 2010).

20 Rachmadi Usman, Hukum Persaingan Usaha Di Indonesia, (Jakarta: Sinar Grafika, 2013), 283.

21 Didik. J. Rachbini, Ekonomi Politik: Kebijakan Dan Strategi Pembangunan, (Jakarta: Granit, 2004), 124. 
diungkap karena keterbatasan wewenang komisi pengawas persaingan usaha yang terbatas konsep teory liniency program dapat dijadikan sebuah solusi dalam menekan pelanggaran kartel di Indonesia yang mana leniency program ini sebagi bentuk pengecualian terhadap pelaku yang terindikasi melakukan pelanggaran kartel.

Perjanjian penetapan harga atau dikenal price fixing agreement merupakan sebuah tindakan kesepakatan yang dilakukan diantara pelaku usaha untuk menentukan harga mengenai barang atau jasa yang dijual kepada masyarakat atau konsumen dengan menimbulkan kerugia terhadap pelaku usaha pesaing. ${ }^{22}$ Perilaku ini termasuk kepada perjanjian yang bersifat horizontal, demikian perjanjian ini dapat berdampak kepada kurangnya persaingan yang maksimal diantara pelaku usaha, serta dapat bepotensi menghambat pesaing baru unuk bersaing pada pasar sejenis. Hal tersebut akan mengakibatkan harga dapat dikontrol oleh pelaku usaha dan pesaingnya dengan melakukan perjanjian pembatasan produk dan sebagainya, dengan adanya pihak yang

22 Rachmadi Usman, Hukum Persaingan Usaha Di Indonesia, (Jakarta: Sinar Grafika, 2013), 212. dirugikan. ${ }^{23}$

Dalam hukum persaingan usaha tidak melarang kegiatan penguasaan pasar apabila diperoleh secara natural dan tidak merugikan kepentingan pihak lain. Parameter dalam menentukan persaingan yang wajar dapat dilihat apabila para pelaku usaha bersaing untuk mendapatkan konsumen dengan meningkatkan kualitas produk masing-masing untuk ditawarkan, terhindar dari kegiatan yang menyimpang dan kegiatan dilarang yang dapat mengakibatkan pelanggaran terhadap aturan perundang-undangan terkait, serta menciptakan keleluasaan bagi pelaku usaha lain untk bersaing tanpa tekanan untuk masuknya pelaku usaha pesaing (barrier to entry) dapat dijadikan sebagai tolak ukur dalam menentukan persaingan usaha yang sehat ${ }^{24}$

Pelanggaran persaingan usaha sendiri didasasri karena adanya persaingan antar pelaku usaha sejenis, maka adanya persaingan diantara pelaku usaha menimbulkan berbagai cara dan strategi pasar yang tidak dibenarkan dalam prinsip persaingan yang sehat dalam memperoleh

23 Ningrum Natasya Sirait, Asosiasi \& Persaingan Usaha Tidak Sehat, (Medan: Pustaka Bangsa Press, 2003), 21.

${ }^{24}$ Susanti Adi Nugroho, Hukum Persaingan Usaha Di Indonesia, (Jakarta: kencana prenada media group, 2012), 233. 
konsumen, bahkaan tidak memperhatikan peraturan yang berlaku dengan tujuan memperoleh konsumen dalam pangsa pasar, maka tidak menutup kemungkinan pula pelanggaran-pelanggaran lain terhadap persaingan akan terus terjadi di sektor penerbangan.

Teori yang di gunakan dalam pembahasan menggunakan teori bentuk dan sifat hubungan hukum ${ }^{25}$ dalam pelayanan bagi kepentingan publik yang merupakan kajian untuk mencermati hubungan antara kebijakan pemerintah yang memberikan hak monopoli kepada perusahaan negara. Berdasarkan Pasal 51 Undang-Undang Nomor 5 Tahun 1999 dinyatakan bahwa pemerintah dapat melakukan monopoli, dapat dipahami bahwa BUMN sebagai badan hukum publik yang dibentuk oleh pemerintah merupakan subjek hukum yang dapat berbuat berbagai tindakan atau perbuatan hukum berkaitan dalam melaksanakan hubungan hukum, pengelolaan harta kekayaan sendiri, kepengurusan perusahaan, pemenuhan hak dan kewajiban, serta mampu menggugat atau digugat dimuka pengadilan.

${ }^{25}$ Chaidir Ali, Badan Hukum (Bandung: PT. Alumni, 2005), hlm. 21.
Teori lain yang digunakan adalah teori organ, dimana BUMN merupakan badan hukum sebagai subjek hukum realitas, dalam kata lain tidak bertindak sendiri, hal ini dalam pelaksanaanya terdapat organnya yaitu komisaris dan direksi guna mencapai tujuan organ tersebut. $^{26}$ Dalam teori organ ini membahas bagaimana bentuk dan sifat hubungan hukum dalam pelayanan bagi kepentingan publik yang merupakan kajian untuk mencermati hubungan antara kebijakan pemerintah yang memberikan hak monopoli kepada BUMN dengan kewenangan yang dimiliki BUMN tersebut dalam mengelola berbagai sektor dalam sumber daya alam dan berbagai cabang produksi penting bagi kelangsungan hidup masyarakat banyak.

\section{Dasar pertimbangan KPPU dalam memutus pelanggaran terhadap persaingan usaha yang dilakukan oleh BUMN (studi kasus Putusan Nomor 15/KPPU/2019)}

PT. Garuda Indonesia dan beberapa maskapai lainnya sebagai maskapai penerbangan dibawah naungan BUMN sebagai perwakilan dari negara yang

\footnotetext{
${ }^{26}$ E. Utrecht dan Mohammad Saleh Djindang, Pengantar Dalam Hukum Indonesia, (Jakarta: PT.Ichtiar Baru, 1983), hlm. 41.
} 
diamanatkan untuk menjamin kesejahteraan masyarakat. Dalam sistem monopoli BUMN sejatinya negara dapat berfungsi sebagai regulator, korporator, dan pelindung rakyat dalam mencegah pemusatan ekonomi oleh satu pelaku atau sekelmpok pelaku usaha. ${ }^{27}$ Pemberian hak monopoli pasar yang di miliki BUMN tidak melanggar persaingan usaha apabila dijalankan berdasarkan batasan-batasan yang termuat dalam Undang-Undang. Good corporate govermen dikenal sebagai tolak ukur dalam pelaksanaan kegiatan usaha yang dilakukan pemerintah yang memuat asas dalam melakukan kegiatan usaha dalam pangsa pasar. Hal ini pula dapat dijadikan sebagai tolak ukur KPPU dalam memutus pelanggaran terhadap persaingan usaha yang dilakukan oleh perusahaan milik negara atau BUMN. Bahwasannya didalam Putusan perkara Nomor 15/KPPU-I2019 telah melanggar prinsip Good Corporate Govermen yang mana ditafsirkan sebagai pedoman perusahaan untuk diarahkan dan dikontrol dengan maksud agar memperoleh keselarasan dalam prinsip pertanggungjawaban terhadap stakeholder

27 Aminuddin IImar, "Hak Menguasai Negara Dalam Privatisasi BUMN" (Jakarta: kencana prenada media group, 2012), 74 . dengan menjamin dan memperhatikan berbagai peraturan kewenangan pemilik, direktur, pemegang saham, masyarakat sebagai konsumen, serta pemerintah. ${ }^{28}$

Inti dari pelaksanaan sistem good corporate govermence memuat berbagai prinsip dalam menjalankan perusahaan untuk dapat mencermati kesepadanan dari kewenangan yang dimiliki dalam menjalankan perusahaan dengan memperhatikan pemegang saham serta kepentingan masyarakat luas atau konsumen yang menjadi sasaran utama dalam pangsa pasar. Dengan memperhatikan pula keselarasan antara kewenangan direksi, komisaris, dan pemegang saham perlu diatur dengan sebaik mungkin.

Menurut Toto pranoto, pada praktiknya seringkali menghadapi berbagai tantangan yang menghambat kegiatan pelaksanaan good corporate govermence BUMN, terdapat tiga faktor utama yang dapat mempengaruhinya. Pertama, adanya kepentingan dari pemerintah dalam setiap tindakan perusahaan yang kadang kala tidak sesuai dengan aturan, yang

\footnotetext{
28 Indra Surya \& Ivan Yustiavandana, Penerapan Good Cor Porate Governance (Mengesampingkan Hak-Hak Istimewa Demi Kelangsungan Usaha, (Jakarta: kencana prenada media group, 2006), 25.
} 
menyebabkan manajemen BUMN kesulitan dalam menentukan objektifitas perusahaan. Kedua, adanya campurtangan politik dalam penempatan direksi, sehingga adanya keterbatasan kewenangan yang dimiliki manajemen sehingga menghambat dalam mengambil keputusan yang objektif. Faktor ketiga, adanya sistem insentif yang kurang menarik diberikan kepada manajemen yang menyebabkan kinerja yang kurang maksimal karena terbentur dengan berbagai batasan. ${ }^{29}$

Pengaturan mengenai berbagai prinsip good corporate govermence pada BUMN tertuang didalam Keputusan Mentri BUMN Nomor: PER-01/MBU/2011 tentang penerapan tata Kelola perusahaan yang baik (good corporate govermence) Pasal 3, bahwa pertama mengenai prinsip transparansi, yang mana penerapan keterbukaan di setiap pengambilan keputusan dan penerapan keterbukaan di setiap penyampaian informasi mengenai perusahaan. Kedua mengenai prinsip akuntabilitas, yang mana mengenai kepastian fungsi, pelaksanaan dan pertanggungjawaban organ dengan maksud agar setiap pelaksanaan kegiatan

${ }^{29}$ Toto Pranoto, Privatisasi, GCG Dan Kinerja BUMN, (Jakarta: Lembaga Management Fakultas Ekonomi UI, 2010). perusahaan yang efektif. Ketiga tentang pertanggungjawaban (responsibility), yang mana mengenai pengelolaan perusahaan dengan memperhatikan kesesuaian terhadap muatan yang terdapat dalam regulasi peraturan perundang-undangan serta prinsip korporasi yang sehat. Keempat, mengenai prinsip Kemandirian (independency), yang berkaitan mengenai pengelolaan kegiatan perusahaan dilakukan dengan cara professional tidak adanya muatan kepentingan pribadi dari setiap tindakan yang telah menyimpanng atas peraturan perundang-undangan serta prinsip korporasi yang sehat. Prinsip kelima, megenai prinsip kewajaran (fairness) yang mana mengenai upaya pemenuhan hak pemangku kepentigan akibat dari adanya suatu perjanjian dan peraturan perundang-undangan, berhubungan mengenai keadilan dan kesetaraan stakeholders perusahaan. ${ }^{30}$ Dalam melaksanakan berbagai prinsip good corporate govermence dalam pengelolaan BUMN termuat pada keputusan mentri dengan tujuan agar pengelolaan BUMN yang lebih kompetitif dalam pangsa pasar, sehingga perusahaan

\footnotetext{
${ }^{30}$ Keputusan Menteri Negara BUMN Nomor: PER-01/MBU/2011 Tentang Penerapan Tata Kelola Perusahaan Yang Baik (Good Corporate Governance) Pada BUMN.
} 
milik negara dapat terhindar dari pelanggaran terhadap persaingan.

Pelaksanaan prinsip good corporate govermence pada BUMN diatur dalam Pasal 4 Keputusan Mentri BUMN Nomor: PER-01/MBU/2011 pada BUMN ${ }^{31}$, bertujuan :

1. Mampu memaksimalkan daya saing BUMN dengan mampu bersaing dipasar dalam maupun luar negeri, sehingga tercapainya tujuan dari BUMN itu sendiri;

2. Dapat memacu penyelenggaraan BUMN secara profesional, efisien, dan efektif, dengan mampu memberdayakan serta meninngkatkan fungsi independensi organ persero dan organ perum;

3. Dapat meningkatkan kesadaran atas tanggungjawab sosial yang dimiliki BUMN atas kepentingan maupun kelestarian lingkungan di sekitar BUMN dan mengoptimalkan peran organ persero dan organ perum disetiap pengambilan keputusan dan melaksanakan setiap perbuatan didasari pada nilai moral yang luhur

${ }^{31}$ Pasal 4 Keputusan Menteri Negara BUMN Nomor: PER-01/MBU/2011 Tentang Penerapan Tata Kelola Perusahaan Yang Baik (Good Corporate Governance) Pada BUMN serta ketaatan terhadap peraturan perundang-undangan;

4. Mampu meningkatkan peranan BUMN untuk berkontribusi dalam perekonomian nasional;

5. Mampu menciptakan peningkatan ekonomi melalui investasi.

Berdasaarkan kasus perkara yang termuat dalam putusan Nomor 15/KPPU/2019 bahwa PT. Garuda Indonesia dan maskapai lain dibawah naungan BUMN lainnya telah mencederai prinsip good corporate govermence selaku perusahaan milik negara untuk melaksanakan peran pemerintah dalam melayani pelayanan publik. Penerapan prinsip good corporate government diharapkan agar perusahaan memiliki tanggung jawab terhadap stakeholders. Prinsip pertanggungjawaban berkaitan erat dengan moral setiap manusia, manusia dalam mengelola perusahaan harus mampu bertanggung jawab atas setiap peraturan yang dibuatnya. Dalam lingkup hukum positif di Indonesia sebuah aturan ditetapkan pada perundang-undangan untuk dapat dijadikan sebuah ukuran mengenai kemanfaatan dan pengaruh. ${ }^{32}$

\footnotetext{
32 Sukarno Aburaera, "Filsafat Hukum Teori Dan Praktek" (Jakarta: kencana prenada media group, 2013), 159.
} 
Dan kasus perkara yang termuat dalam putusan Nomor 15/KPPU/2019 telah mencederai prinsip kemandirian, mengenai penerapan perlakuan adil sehubungan dengan pemenuhan hak stakeholder berlandaskan pada perundang-undangan yang berlaku. Melalui sistem fariens atau Kesetaraan dan Kewajaran bisa diterapkan sebagai faktor yang bisa mendorong sebagai memonitoring dan memberikan jaminan terlaksananya perlakuan yang adil bagi pelaku usaha didalam pangsa pasar.

Hal ini yang yang dapat dijadikan pertimbangan oleh KPPU dalam kasus serupa yakni pelanggaran-pelanggaran terhadap persaingan usaha yang dilakukan oleh BUMN. Dalam Putusan Nomor 15/KPPU-I/2019 tindakan yang dilakukan PT. Garuda Indonesia serta maskapai lainnya yang terlibat dinyatakan bersalah melakukan pelanggaran terhadap persaingan usaha berdasarkan pada Pasal 5 Undang-Undang Nomor 5 Tahun 1999 mengenai pengaturan penetapan harga. Namun demikian pada perkara ini, Majelis Komisi menilai prilaku concerted action yang terjadi pada para terlapor sebagai wujud meeting of minds diantara para terlapor, sehingga tidak terpenuhinya unsur perjanjian pada Pasal 11. Oleh sebab itu seluruh terlapor terbebas dari ancama Pasal 11.
Perkara ini diusut karena adanya penelitian inisiatif dari Komisi Pengawas Persaingan Usaha dengan membentuk tim monitioring atas pelayanan jasa angkutan udara niaga pelayanan angkutan kelas ekonomi dengan ruter penerbangan pelayanan dalam negeri. Atas dasar kegiatan yang dilakukan para pihak didalam perkara yang terdapat dalam Putusan Nomor 15/KPPU-I/2019 perilaku yang terjadi oleh para perusahaan penerbangan yang berdasarkan pembuktian yang dilakukan majelis komisi bahwasanya telah terpenuhinya unsurunsur yang terdapat pada Perkom Nomor 4 Tahun 2011 acuan terhadap pelanggaran Pasal 5 Undang-Undang Nomor 5 Tahun 1999 yang mana dalam Putusan Nomor 15/KPPU-I/2019, sebagai berikut:

1. Unsur pelaku usaha. Perusahaan atau para pelaku usaha pesaing yang melakukan kesepakatan penetapan harga pada Putusan Nomor 15/KPPUI/2019 yaitu Terlapor I (PT Garuda Indonesia) Persero Tbk, sebagai Terlapor II PT (Citilink Indonesia), Terlapor III (PT Sriwijaya Air), Bahwa Terlapor IV (PT NAM Air), Bahwa Terlapor V (PT Batik Air Indonesia), Bahwa Terlapor VI (PT Lion Mentari), sebagai Terlapor VII (PT Wings Abadi). Dalam hal ini 
semua pelaku usaha tersebut berdasarkan surat izin pendirian PT para pelaku usaha merupakan badan hukum yang dibuat dan berkedudukan di wilayah yurisdiksi hukum Indonesia serta menyelenggarakan aktifitas usahanya di Indonesia.

2. Unsur perjanjian. Bahwasannya dalam perkara yang terjadi tidak terdapat perjanjian tertulis akan tetapi perilaku concretd action atau parallelism yang dilakukan para terlapor, termasuk perilaku penetapan harga secara bersamasama (concerted action) dalam bentuk pencabutan izin rute atau pengurangan frekuensi, concerted action atau parallelism yang didukung adanya plus factors sehingga concerted action ini bukan merupakan tindakan independen dari para terlapor, melainkan sebagai hasil kesepakatan para Terlapor (meeting of minds). yang didukung oleh plus factors tidak didasarkan pada tindakan independen dari para terlapor melainkan berdasarkan kesepakatan meeting of minds berupa kesamaan prilaku meniadakan diskon pada waktu yang hampir bersamaan dan membuat kesepakatan berupa meniadakan tiket harga yang rendah di pasar untuk membatasi ketersediaan serta untuk menjaga harga tinggi pada layanan jasa angkutan udara niaga penerbangan domestik kelas ekonomi, sehingga masuk dalam kesepakatan yang tidak diperbolehkan menurut Undang-Undang Nomor 5 Tahun 1999. ${ }^{33}$

3. Unsur menetapkan harga, adapun unsur yang dilakukan para pelaku berdasarkan Putusan Nomor 15/KPPU-I/2019 yaitu penetapan harga, yang mana para terlapor yang terlibat dipengaruhi aksi serta reaksi pesaing dengan cara saling melihat harga. Hal ini dipermudah oleh pemasaran yang luas dan mudahnya akses melihat harga pesaing sehingga memungkinkan terjadinya kontak multi-pasar; Bahwa pelaku usaha angkutan udara niaga berjadwal menggunakan strategi dynamic pricing yaitu perubahan harga dilakukan setiap saat dengan melihat harga pelaku usaha lain dengan melakukan monitoring harga dalam 1 (satu) hari, para Terlapor secara bersamaan menetapkan harga tidak berdasarkan kondisi pasar mengikuti permintaan peak season dan low season sehingga mengakibatkan harga

\footnotetext{
${ }^{33}$ Putusan 15/KPPU-I/2019 HIm. 994
} 
tinggi di konsumen. kesamaan perilaku Para Terlapor tidaklah mungkin terjadi di pasar yang kompetitif jika tidak ada kesepakatan yang dilakukan sebelumnya. Bahwa merujuk pada Peraturan Komisi Nomor 4 Tahun 2011, menyatakan macam bentuk dari penetapan harga yang tercantum kedalam aturan dari Pasal 5 Undang-Undang Nomor 5 Tahun 1999 yang merupakan bentuk kesepakatan menghilangkan diskon atas tiket yang ditawarkan, dan membuat keseragaman berupa mentiadakan harga tiket murah sehingga mengendalikan ketersediaan untuk menjaga harga tetap tinggi.

4. Unsur pasar bersangkutan indikasi adanya dugaan pelanggaran terhadap persaingan usaha didasari pada pengertian produk sera pasar bersangkutan. Proses analisi mengenai pasar bersangkutan menjadi tahapan awal dalam menetapkan suatu kasus pelanggaran terhadap persaingan usaha. Sehingga tim peneliti indikasi pelanggaran dapat memperoleh sebuah data informasi mengenai yang tepat mengenai jenis dan karakteristik pasar, pelaku usaha yang berperan, serta dampak yang ditimbulkan mengenai pelanggaran prinsip persaingan usaha yang sehat. Dalam kasus ini yang dimaksud dengan pasar produk ialah layanan jasa angkutan udara niaga berjadwal penumpang kelas ekonomi. Sedangkan dalam kasus ini yang dimaksud dengan pasar geografis ialah seluruh rute penerbangan dalam negeri. ${ }^{34}$

5. Unsur pelaku usaha pesaing. Bahwa dalam perkara a quo, Terlapor I (PT Garuda Indonesia) Persero Tbk, sebagai Terlapor II PT (Citilink Indonesia), Terlapor III (PT Sriwijaya Air), Bahwa Terlapor IV (PT NAM Air), Bahwa Terlapor V (PT Batik Air Indonesia), Bahwa Terlapor VI (PT Lion Mentari), sebagai Terlapor VII (PT Wings Abadi). Yakini sebagai pelaku usaha yang menjalankan kegiatan usahanya pada pasar sejenis yakni menyediakan jasa pengangkutan transportasi udara dengan cakupan wilayah indonesia atau dalam negri

6. Unsur konsumen. Bahwa konsumen adalah setiap pengguna jasa layanan angkutan udara niaga berjadwal penumpang kelas ekonomi untuk semua jenis pelayanan yang membayar sejumlah harga tiket

\footnotetext{
${ }^{34}$ Putusan 15/KPPU-I/2019 HIm. 937
} 
tertentu untuk keperluan pribadi maupun untuk keperluan pihak lain ${ }^{35}$

Dalam putusan 15/KPPU-I/2019 Komisi pengawas menggunakan metode pendekatan per se illegal dalam memutus perkara tersebut, karena pelanggaran terhadap pasal 5 tidak perlu menggunakan penelitian lebih lanjut mengenai dampak dan akibat yang di timbulkan akibat. Metode pendekatan ini sendiri menurut Sutrisno Iwantono, adalah suatu kegiatan melakukan secara inheren yang sifatnya melanggar suatu ketentuan tidak lagi memerlukan pengungkapan fakta mengenai dampak yang ditimbulkan atas suatu tindakan yang dilakukan tersebut ${ }^{36}$. Majelis Komisi hanya melihat unsur formal dugaan adanya pelangaran penetapan harga, yaitu perilaku penetapan harga secara bersamasama (concerted action) dalam bentuk pencabutan izin rute atau pengurangan frekuensi. dimana pendekatan yang melihat kepada ada atau tidaknya perjanjian sebagai unsur formal dengan sendirinya dianggap perilaku illegal atau melawan hukum. Putusan Majelis Komisi hanya menjatuhkan

\footnotetext{
${ }^{35}$ Putusan 15/KPPU-I/2019 HIm. 997

36 Hermansyah, Pokok-Pokok Hukum Persaingan Usaha Di Indonesia, (Jakarta: kencana prenada media group, 2008), 78.
}

hukuman berupa perintah untuk para terlapor agar membatalkan pemberlakuan penetapan harga berdasarkan kesepakatan dan mengumumkan pembatalan tersebut di media. Hal ini dipertimbangkan Majelis KPPU oleh karena melihat keefektivitasan perjanjian tersebut, dimana dalam konsep pendekatan per se illegal pada kasus ini perjanjian merupakan alat pertimbangan oleh Majelis KPPU dalam memutus kasus nomor 15/KPPU-I/2019 dalam hal pelanggaran penetapan harga tanpa sanksi pidana pokok.

Dalam putusan 15/KPPU-I/2019 bentuk dari perjanjian penetapan harga bersifat horizontal, perjanjian yang terjadi diantara pelaku dalam kesepakatan penetapan harga dengan terpenuhinya unsur "pasar bersangkutan yang sama" mengenai larangan Pasal 5. Putusan 15/KPPU-I/2019 memenuhi unsur sebagai perjanjian penetapan harga yang bersifat horizontal, yaitu tingkatan produksi kegiatan usaha dari para terlapor adalah sama ataupun disebut horizontal. Akibat dari adanya perjanjian penetapan harga horizontal itu sendiri akan menimbulkan berbagai hambatan yang bersifat horizontal pula dalam pangsa pasar. Perilaku yang dilakukan pelaku usaha mengenai kesamaan tingkat produksi yang mengadakan penetapan harga jika 
dicermati dari maka harga yang disepakati hanya akan diberlakukan pada tingkat produksi yang sama. Dampak dari penetapan harga horizontal harga yang dihasilkan tidak dapat serta merta diberlakukan pada pelaku usaha yang berada pada tingkat lainnya, kendatipun tidak menutup kemungkinan akan dapat mempengaruhi harga pada tingkat produksi yang berada dibawahnya.

Dalam sistem peradilan yang lebih modern dan terbatasnya wewenang KPPU dalam menangani suatu perkara penting rasanya bagi KPPU untuk mendesak amendemen Undang-Undang No. 5 Tahun 1999 dengan mengusung penerapan konsep liniency program untuk membongkar pelanggaran terhadap persaingan khususnya praktik penetapan harga di Indonesia seperti kasus yang tertuang dalam putusan 15/KPPU-I/2019. Konsep linuency program ini diusung untuk menekan angka pelanggaran terhadap persaingan, yaitu adanya pengecualian bagi pelaku pelanggaran terhadap persaingan yang mengaku dan memberikan informasi kepada komisi pengawas persaingan usaha akan mendapatkan amnesti atau insentif berupa keringanan hukuman, dengan adanya kewajiban bagi pelaku usaha tersebut untuk memberikan kemudahan akses data dan informasi kepada KPPU terhadap prilaku yang dilakukan dilakukan pelanggaran terhadap persaingan usaha yang dilakukan, hal ini karena keterbatasan wewenang yang dimiliki KPPU sehingga sulit dibuktikan, seperti masalah kartel dan prnrtapan harga yang terjadi diantara pelaku usaha dalam kasus yang diangkat didalam penelitian ini, dengan maksud agar memperoleh data informasi awal mengenai indikasi kartel yang terjadi. ${ }^{37}$ Adanya pemberian amnesti atau insentif keringan hukuman bagi pelaku yang mengaku dan atau memberikan informasi ke KPPU. Keterlibatan berbagai pihak dalam upaya menekan angka pelanggaran terhadap persaingan akan memberikan kesadaran bagi setiap pelaku usaha senantiasa dalam melakukan setiap kegiatannya berdasarkan hukum dan aturan yang berlaku. Penerapan konsep leniency program ini sudah diterapkan dibeberapa negara dan terbukti sukses dan efektif dalam pembuktian atas pelanggaran persaingan usaha yang sulit dibuktikan seperti kasus kartel, persaingan usaha dan lainnya, seperti Amerika Serikat, Uni Eropa,

37 Riris Munadiya, Bukti Tidak Langsung (Indirect Evidence) Dalam Penanganan Kasus Persaingan Usaha," Jurnal Persaingan Usaha Edisi 5, 2011, 166. 
Jepang dan Denmark yang telah sukses menerapkan leniency program. ${ }^{38}$

\section{Kesimpulan}

BUMN adalah perusahaan negara yang diberikan pengecualian untuk memonopoli pangsa pasar demi kepentingan dan kesejahteraan orang banyak, pemberina pengecualian untuk memonopoli pasar tidak serta merta membuat BUMN terhindar dari pelanggaran persainan usaha. Dalam hal ini perusahaan penerbangan dibawah naungan BUMN yang terbukti melakukan pelanggaran terhadap pasal 5 UndangUndang Nomor 5 Tahun 1999 prihal prilaku perjanjian penetapan harga. Dalam hal ini PT. Garuda Indonesia, PT Citilink Indonesia, PT Sriwijaya Air, PT NAM Air, PT Batik Air Indonesia, PT Lion Mentari, PT Wings Abadi. Yang mana terpenuhinya unsur penetapan harga berdasarkan peraturan komisi pengawas persainan usaha Nomor 04 Tahun 2011. Metode pendekatan per se illegal digunakan dalam perkara ini, yakni tanpa memerlukan penelitian lanjutan mengenai dampak yang ditimbulkan atas perbuatan yang diduga

${ }^{38}$ Anna Maria Tri Anggraini, "Program Leniency Dalam Mengungkap Kartel Menurut Hukum Persaingan Usaha," Jurnal Persaingan Usaha Edisi 6, 2011, 107. melanggar persaingan usaha. Penetapan harga dalam kasus ini bersifat horizontal yang mana akan menimbulkan hambatan yang bersifat horizontal dalam suatu pasar. Sebab dilihat dari kesamaan tingkat produksi para pelaku usaha yang mengadakan penetapan harga maka harga yang disepakati hanya akan diberlakukan pada tingkat produksi yang sama. Good corporate govermence dapat dijadikan sebagi acuan bagi KPPU dalam menentukan setiap tindakan yang dilakukan oleh perusahaan BUMN didalam pangsa pasar bersifat mendorong atau menghambat persaingan.

\section{Daftar Pustaka}

\section{Buku}

Aminuddin Ilmar, Hak Menguasai Negara Dalam Privatisasi BUMN, Jakarta : Kencana Prenada Media Group, 2012.

Anang Triyono, Penyalahgunaan Posisi Dominan Oleh Pelaku Usaha: Studi Kasus Pada Audit PT Telekomunikasi Indonesia Tbk, Jakarta : Universitas Indonesia, 2010.

Andi Fahmi Lubis dkk, Hukum Persaingan Usaha Antara Teks Dan Konteks, Jakarta : KPPU, 2009.

\section{, Hukum Persaingan Usaha Antara} Teks Dan Konteks, Jakarta: KPPU, 2009.

, Hukum Persaingan Usaha Antara Teks Dan Konteks, Jakarta: KPPU, 
2009.

Binoto Nadapdap, Hukum Acara Persaingan Usaha, Jakarta : Jala Permata Aksara, 2009.

Chaidir Ali, Badan Hukum, Bandung : PT. Alumni, 2005.

Didik. J. Rachbini. "Ekonomi Politik: Kebijakan Dan Strategi Pembangunan," 124. Jakarta: Granit, 2004.

E. Utrecht dan Mohammad Saleh Djindang, Pengantar Dalam Hukum Indonesia, Jakarta : PT.Ichtiar Baru, 1983.

Gunawan Widjaja, Seri Hukum Bisnis Marger Dalam Perspektif Monopoli, Jakarta: Raja Grafindo Persada, 2002.

Hermansyah, Pokok-Pokok Hukum Persaingan Usaha Di Indonesia, Jakarta : Kencana Prenada Media Group, 2008.

Indra Surya \& Ivan Yustiavandana, Penerapan Good Cor Porate Governance (Mengesampingkan HakHak Istimewa Demi Kelangsungan Usaha), Jakarta : Kencana Prenada Media Group, 2006.

Knud Hansen, Undang-Undang Larangan Praktek Monopoli Dan Persaingan Usaha Tidak Sehat, Jakarta: PT Tema Baru, 2002

Mudrajat Kuncoro, Strategi Bagaimana Meraih Keunggulan Kompetitif, Jakarta: Erlangga, 2005.

Ningrum Natasya Sirait, Asosiasi \& Persaingan Usaha Tidak Sehat, Medan: Pustaka Bangsa Press, 2003.

Rachmadi Usman, Hukum Persaingan Usaha Di Indonesia, Jakarta:
Gramedia Pustaka Utama, 2004.

Sukarno Aburaera, Filsafat Hukum Teori Dan Praktek, Jakarta: Kencana Prenada Media Group, 2013.

Susanti Adi Nugroho, Hukum Persaingan Usaha Di Indonesia, Jakarta: Kencana Prenada Media Group, 2012.

Toto Pranoto, Privatisasi, GCG Dan Kinerja BUMN, Jakarta: Lembaga Management Fakultas Ekonomi UI, 2010 .

\section{Karya Ilmiah}

Anna Maria Tri Anggraini. "Program Leniency Dalam Mengungkap Kartel Menurut Hukum Persaingan Usaha.” Jurnal Persaingan Usaha Edisi 6, 2011.

Hutagaol, Penerbangan Perintis Dalam Mengembangkan Perekonomian Di

Pulau Karimun Jawa, Jurnal Manajemen Transportasi \& Logistik Vol. 05 No. 2, 2018.

Riris Munadiya, Bukti Tidak Langsung (Indirect Evidence) Dalam Penanganan Kasus Persaingan Usaha, Jurnal Persaingan Usaha Edisi 5, 2011.

\section{Website}

KPPU. "Siaran Pers - KOMISI
PENGAWAS
USAHA, hERSAINGAN
pers/, diakses 28 Desember 2020.
pukul 15.20 WIB




\section{Peraturan Perundang-Undangan}

Undang-Undang Dasar1945

Undang-Undang Nomor 19 Tahun 2003

Tentang Badan Usaha Milik Negara

Undang-Undang Nomor 5 Tahun 1999

Tentang Larangan Praktik Monopoli

Dan Persaingan Usaha Tidak Sehat.

Undang-Undang Nomor 1 Tahun 2009

Tentang Penerbangan
Keputusan Menteri Negara BUMN
Nomor : PER-01/MBU/2011 Tentang
Penerapan Tata Kelola Perusahaan
Yang Baik (Good Corporate
Governance)

Putusan 15/KPPU-I/2019 